\title{
ANTIMICROBIAL AND CYTOTOXIC EFFECTS OF ENDOPHYTIC STREPTOMYCES STRAINS ISOLATED FROM CINNAMOMUM CASSIA PRESL IN VIETNAM
}

\author{
Nguyen Quang Huy ${ }^{1,2,3,}$, Vu Thi Hanh Nguyen ${ }^{2, *}$, Nguyen Van The ${ }^{2}$, Bui Thi Lien ${ }^{2}$, Le Thi Thu Hang ${ }^{3}$, \\ Phi Quyet Tien ${ }^{1,2, 凶}$ \\ ${ }^{I}$ Graduate University of Science and Technology (GUST), Vietnam Academy of Science and Technology \\ (VAST), Hanoi, Vietnam \\ ${ }^{2}$ Institute of Biotechnology (IBT), Vietnam Academy of Science and Technology (VAST), Hanoi, Vietnam \\ ${ }^{3}$ University of Science and Technology of Hanoi (USTH), Vietnam Academy of Science and Technology (VAST), \\ Hanoi, Vietnam
}

*: These authors contributed equally to the works

${ }^{\square}$ To whom correspondence should be addressed. E-mail: tienpq@ibt.ac.vn

Received: 15.02 .2019

Accepted: 27.5.2019

\section{SUMMARY}

Vietnam is recognized as one of the countries with the high diversity of medicinal plant species in the world, nevertheless little is known about the distribution, diversity and biological activity of endophytic actinomycetes associated with host plants. The present study aimed to evaluate antimicrobial and cytotoxic activities of four endophytic Streptomyces strains including Streptomyces sp. HBQ75, HBQ87, HBQ102 and HBQ104 isolated from different organs (roots, stems or leaves) of Cinnamomum cassia Presl. Analysis of 16S rRNA gene sequences and the phylogenetic tree assigned them to four different Streptomyces species as follow Streptomyces fulvissimus HBQ75, Streptomyces parvulus HBQ87, Streptomyces pratensis HBQ102 and Streptomyces ribosidificus HBQ104. These strains exhibited broad antimicrobial spectrum against at least five out of nine pathogens tested, among them $S$. parvulus HBQ87 showed the best activity (inhibition zones $>20 \mathrm{~mm}$ ). Interestingly, S. parvulus HBQ87 carried all three genes ( $p k s-\mathrm{I}, p k s$-II and $n r p s$ ) encoding for polyketide synthase or non-ribosomal peptide synthetase enzymes involved in biosynthesis of secondary metabolites, while the remaining strains only possessed one or two genes. All the Streptomyces strains were positive for the anthracyclines-like antibiotic activity. The cell-free supernatants of $S$. parvulus HBQ87 revealed remarkable inhibitory effects against all three human cacinomar cell lines including hepatoma Hep3B, breast adenocarcinoma MCF7 and lung cancer A549 cells at both concentrations tested $(30 \mu \mathrm{g} / \mathrm{mL}$ and $100 \mu \mathrm{g} / \mathrm{mL})$, while $S$. fulvissimus HBQ75 and $S$. pratensis HBQ102 were active against only Hep3B and MCF7 cells. In conclusion, the phenotypic and genotypic features of the four endophytic Streptomyces strains suggest that they have a capacity to produce different broad-spectrum secondary metabolites. Among them, S. parvulus HBQ87 could be the most potential candidate for the production of important antimicrobial and antitumor compounds.

Keywords: Antimicrobial activity, antitumor activity, anthracyclines, Cinnamomum cassia, endophytic actinomycetes

\section{INTRODUCTION}

Antibiotic plays a crucial role in the treatment of infectious diseases. However, the abuse of antibiotics has become a major factor leading to the emergence of antibiotic and multi-antibiotic resistant pathogens (Ventola, 2015). Therefore, the screening and developing new antibacterial agents having broadspectrum antimicrobial activity, novel mode of action or multiple targets are needed to limit the emergence of multidrug resistance (Ventola, 2015). Out of
70,000 microbially-derived compounds, approximately 20,000 compounds are origined from actinomycetes (Bérdy, 2012). It is worth noting that approximately $60 \%$ of antibiotics used in clinical practices are derived from Streptomyces genus. This highlights that Streptomyces is the most important producer of valuable secondary metabolites in the nature.

Screening of endophytic actinomycetes associated with medicinal plants has gained interest 
due to the interaction and evolution of them within the host plants that might lead to the production of different and novel bioactive compounds (Christina et al., 2013; Matsumoto, Takahashi, 2017). Recently, many important bioactive products such as antibiotic, antifungal, antiparasitic, antiviral and antitumor agents have been isolated in endophytic actinomycetes (Christina et al., 2013). Globally, endophytic Streptomyces genus is dominant within host plants (Golinska et al., 2015). Accordingly, many novel antibiotics have been mainly found in endophytic Streptomyces species including munumbicins, kakadumycins, 4-arylcoumarin analogs, anthracyclines, naphthomycin $\mathrm{K}$ and brartemicin which were active against various serious human pathogens and different cancer cell lines (Christina et al., 2013; Golinska et al., 2015). Interestingly, the capacity to produce a huge number of bioactive compounds differs greatly between and within Streptomyces species if they are isolated from different host plants (Christina et al., 2013; Golinska et al., 2015; Matsumoto, Takahashi, 2017). In addition, many endophytic Streptomyces species possess various biosynthetic gene clusters for secondary metabolites, particularly the most important enzymes polyketide synthase (PKS) and non-ribosomal peptide synthetase (NRPS) (Golinska et al., 2015). Thus, studying the phenotypic characteristics combined with genotypic features would gain insight into the potential of endophytic actinomycete strains associated with medicinal plants for producing new antibiotics and other bioactive compounds (Christina et al., 2013; Golinska et al., 2015).

Vietnam is a tropical country with variety of plant species. The country has over 3,800 medicinal plant species accounted for approximately $11 \%$ of the 35,000 species of medicinal plants known wordwide (http://vea.gov.vn/en/icorperation/Projects/Pages/the \%20Biodiversity $\% 20$ Partnership $\% 20$ Forum $\% 20201$ 9.aspx). This is the potential source for the isolation of endophytic actinomycetes producing valuable secondary metabolites. Unfortunately, so far very few studies on the distribution and biological characteristics of endophytic actinomycetes from medicinal plants in Vietnam have been published (Phan et al., 2016; Lam, 2017; Vu et al., 2019). In this context, the present study focused on the endophytic actinomycete population associated with Cinnamomum cassia Presl which is widely used in Vietnam as traditional medicine regimen for treating various infections and chronic diseases as well. This study aimed to evaluate antimicrobial and cytotoxic activities of different antibiotics-producing endophytic Streptomyces strains isolated from the host plant C. cassia Presl in Hoa Binh province, North Vietnam.

\section{MATERIALS AND METHODS}

According to the different morphological and biological features, four endophytic actinomycetes strains belonged to the Streptomyces genus including Streptomyces sp. HBQ75, Streptomyces sp. HBQ87, Streptomyces sp. HBQ102 and Streptomyces sp. HBQ104 were isolated from different organs of $C$. cassia Presl in Hoa Binh province $\left(20^{\circ} 47^{\prime} 21^{\prime \prime} \mathrm{N}\right.$; $105^{\circ} 21$ ' $20^{\prime}$ ' $\mathrm{E}$ ) were selected for the present study.

The YIM38 medium was used for studying antibiotics production of the endophytic actinomycetes strains selected. The composition of YIM38 medium $(\mathrm{g} / \mathrm{L})$ includes: malt extract 4.0 ; yeast extract 4.0; glucose 4.0; agar 20.0 and distilled water 1000 mL; pH 7.2 (Khieu et al., 2015; Vu et al., 2018).

Human pathogens including Salmonella Typhimurium ATCC 14028, Escherichia coli ATCC 11105, Sarcina lutea ATCC 9341, Bacillus cereus ATCC 11778, Proteus vulgaris ATCC 49132, Pseudomonas auroginosa ATCC 9027, Candida albicans ATCC 10231, Enterobacter aerogenes ATCC 13048 and methicillin-resistant Staphylococcus epidermidis ATCC 35984 (MRSE) were used as indicator microorganisms for the screening antimicrobial activity of cell-free supernatants from culture broth of Streptomyces strains using the agar well-diffusion method.

Human hepatoma Hep3B, human breast adenocarcinoma MCF7 and human lung cancer A549 cell lines were kindly prodived by Prof. Jeong-Hyung Lee, Department of Biochemistry, College of Natural Sciences, Kangwon National University, Korea for the evaluation of cytotoxic effects of ethyl acetate extract of Streptomyces species. Standard antibiotic camptothecin was used as a positive control.

\section{Screening for antimicrobial activity}

Endophytic actinomycetes were cultivated in the YIM38 culture broth at $30^{\circ} \mathrm{C}$ with shaking 200 $\mathrm{rpm} / \mathrm{min}$, for 7 days. The YIM38 culture broth of actinomycete strains were centrifuged at 10.000 $\mathrm{rpm} / \mathrm{min}$ for $10 \mathrm{~min}$, then the supernatances were passed $0.22 \mu \mathrm{L}$ filters. The cell-free supernatants of Streptomyces strains were used for the evaluation of 
antimicrobial activity against the nine microbes using the agar well diffusion method as described before (Vu et al., 2018; Vu et al., 2019). The experiments were performed in triplicates.

\section{Screening for the activity of anthracyclines-like antibiotics}

The production of anthracyclines-like antibiotics of the isolated endophytic actinomycetes was screened by pigment tests as previously described (Khieu et al., 2015). The mechanism of the method is as follows: Due to the presence of anthraquinone ring in the chemical composition, the color of anthracycline compounds changes depending on the $\mathrm{pH}$ of the environment. Follow it the orange color can be observed in acid and purple in alkaline environment. This feature is used for preliminary screening of anthracycline productive actinomycetes among the isolated actinomycete strains.

\section{Classification of endophytic actinomycetes based 16S rRNA gene sequence and phylogenetic tree analysis}

Endophytic actinomycetes were cultivated in YIM38 at $30^{\circ} \mathrm{C}$ with shaking $200 \mathrm{rpm} / \mathrm{min}$, for $48 \mathrm{hrs}$. The cell pellets were harvested by the centrifuge at $10.000 \mathrm{rpm} / \mathrm{min}$ in $5 \mathrm{~min}$. Then, total genomic DNA was extracted as previously described by ( $\mathrm{Vu}$ et al., 2019). The amplification of 16 S rRNA gene sequence of the four Streptomyces sp. strains was performed by using the universal primer pair $27 \mathrm{~F}$ (5'TAACACATGCAAGTCGAACG-3') and 1429R (5'GGTGTGACGGGCGGTGTGTA-3') (Vu et al., 2019). The PCR amplicons were sequenced and compared with 16S rRNA sequences in GenBank using the Blast tool (http://blast.ncbi.nlm.nihgov/Blast.cgi).

A molecular phylogenetic tree was computed using the 16S rRNA sequences of four Streptomyces sp. strains obtained and Streptomyces type strains (retrived from GenBank, NCBI). Multiple sequence alignment was performed by using CLUSTALX software and the phylogenetic tree was constructed by neighbor-joining method based on the general time reversible model using MEGA7 sofware (Kumar et al., 2016). Parameters were set as a bootstrap of 1000 replications. The phylogenetic tree was rooted using Bacillus thuringiensis ATCC 10792 (GenBank accession number CP020754) as an out-group. The 16S rRNA gene sequences of the four Streptomyces strains were deposited in GenBank with the accession numbers as follow: HBQ75 (MF796970), HBQ87
(KR076807), HBQ102 (MF796968) and HBQ104 (MF796972).

\section{Detection of biosynthetic genes}

Three sets of degenerate primers: A3F (5'-GCS TAC SYS ATS TAC ACS TCS GG-3') and A7R (5'SAS GTC VCC SGT SCG GTA S-3'), K1F (5'-TSA AGT CSA ACA TCG GBC A-3') and M6R (5'-CGC AGG TTS CSG TAC CAG TA-3'), KSaF (5'-TSG CST GCT TGG AYG CSA TC-3') and KSaR (5'TGG AAN CCG CCG AAB CCG CT-3') were used for amplification of the nrps, pks-I and $p k s$-II genes, respectively (Metsä et al., 1999; Ayuso, Genilloud, 2005). PCR compositions and amplification conditions were performed as previously described (Salam et al., 2017). The PCR amplicons were examined by electrophoresis on $1.5 \%$ agarose gel.

\section{Cytotoxic assay}

The cytotoxicity of ethyl acetate crude extract (EACE) of the four Streptomyces strains were carried out against human carcinoma cell lines using MTT (3(4,5-dimethylthiazol-2-yl)-2,5-diphenyltetrazolium bromide) method as described previously (Khieu et al., 2015; Vu et al., 2018). In brief, approximately $2.5 \times 10^{4}$ cells/well of A549, $5 \times 10^{4}$ cells/well of MCF7 and $2.5 \times 10^{4}$ cells/well of Hep3B were seeded into 96 well plates containing RMPI 1640 medium supplemented with $10 \%$ fetal bovine serum (FBS), $100 \mathrm{U} / \mathrm{mL}$ penicillin, and $100 \mu \mathrm{g} / \mathrm{mL}$ streptomycin. After $24 \mathrm{hrs}$, different concentrations of EACE of actinomycete strains ( 30 and $100 \mu \mathrm{g} / \mathrm{mL}$ ) were added into the plates and incubated at $37^{\circ} \mathrm{C}, 5 \% \mathrm{CO}_{2}$ for 72 hrs. After the incubation period, $20 \mu \mathrm{L}$ of MTT (5 $\mathrm{mg} / \mathrm{mL}$ in PBS) was then added to each well and the plates were incubated at $37^{\circ} \mathrm{C}, 5 \% \mathrm{CO}_{2}$ for $4 \mathrm{hrs}$. The incubation medium was discarded and $200 \mu \mathrm{L}$ of isopropanol was added to dissolve the formazan crystals. The absorbance was measured at $570 \mathrm{~nm}$ using an ExMark microplate reader (Molecular Devices, CA) and cell survival was calculated by the following formula:

\section{Cell Viability $(\%)=$ Test OD/Control OD x 100}

The tests were performed in triplicate. The cell viability value is $\leq 50 \%$ recorded as the positive activity.

\section{Statistical analysis}

The data were expressed as mean \pm standard deviation using Excel 2010 and XLSTAT 2016 
software for analysis of one-site deviation (ANOVA). The $P$ value $\leq 0.05$ were statistically significant.

\section{RESULTS AND DISCUSSION}

\section{Genetic identification of Streptomyces species}

Analysis of the 16S rRNA gene sequences of Streptomyces strains showed high similartities (99$100 \%$ ) with the $16 \mathrm{~S}$ rRNA gene sequences of corresponding reference strains retrived from
GenBank through the BLAST Search tool. In agreement, the phylogenetic tree based on 16S rRNA gene sequences generated by using the neighborjoining method indicated that, strain HBQ75 and Streptomyces fulvissimus strain DSM 40593T was formed a clade. Similarlity, strain HBQ87 and Streptomyces parvulus strain NBRC 13193T, strain HBQ102 and Streptomyce pratensis ATCC 33331, strain HBQ104 and Streptomyces ribosidificus strain NBRC 13796T were formed different clades in the different clusters of the tree (Figure 1).

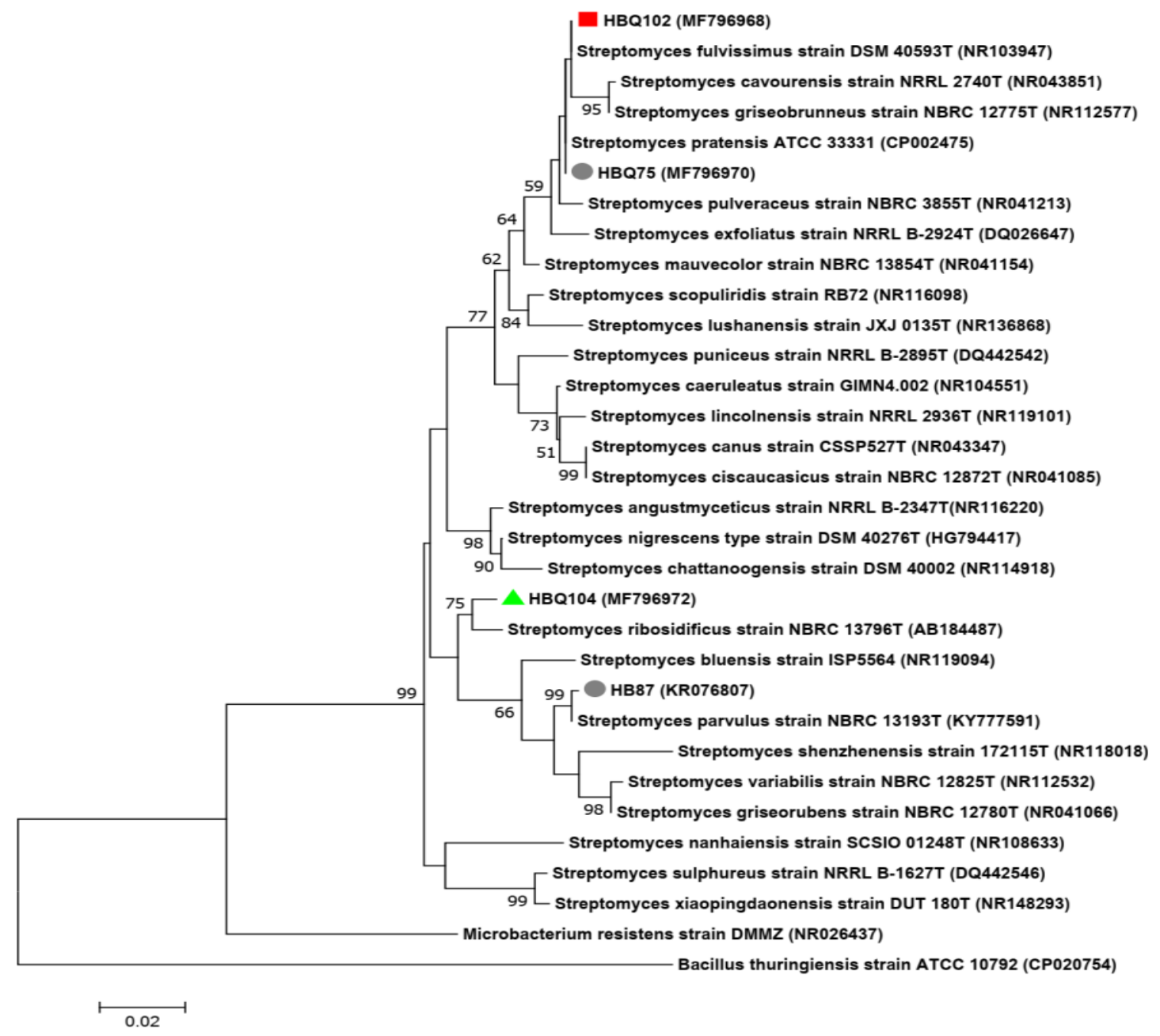

Figure 1. Neighbor-joining phylogenetic tree based on 16S rRNA gene sequences of Streptomyces strains from plants and closely related type strains. The Bacillus thuringinesis strain ATCC 10792 (CP020754) was used as the root of the tree. Numbers at nodes indicate the level of bootstrap support (> 50\%) based on 1000 replications. The scale bar represents 20 nucleotides substitutions per 1000 nucleotides. 
Acorrding to the results of $16 \mathrm{~S}$ rRNA gene sequence; phylogenetic tree analysis, these strains were assigned to the four different species as follow Streptomyces fulvissimus HBQ75, Streptomyces parvulus $\mathrm{HBQ} 87$, Streptomyces pratensis $\mathrm{HBQ} 102$ and Streptomyces ribosidificus HBQ104. In agreement with previous studies worldwide, our study highlighted that endophytic actinomycete belonged to genus Streptomyces is predominant in many different medicinal plants (Qin et al., 2009; Passari et al., 2015). For example, Qin et al. (2009) found that out of 2,174 actinobacterial strains isolated from medicinal plants in a rain forest of Xishuangbanna in China, $87 \%$ were Streptomyces species. Similarly, a study of Passari et al. (2015) also showed that the Streptomyces genus was the most dominant, accounted for $66.6 \%$ of endophytic actinomycetes isolated from medicinal plants in India.

\section{The antimicrobial activity of Streptomyces strains}

Previous studies have demonstrated that endophytic actinomycetes associated with medicinal plants are potential sources of antibiotics and other valuable bioactive compounds (Golinska et al., 2015; Matsumoto, Takahashi, 2017). Here, in the course of screening endophytic actinomycetes producing antibiotics, our study showed that four Streptomyces strains exhibited remarkable board-spectrum antimicrobial activity against $5-6$ microbes tested. The results are shown in the Table 1 and Figure 2.

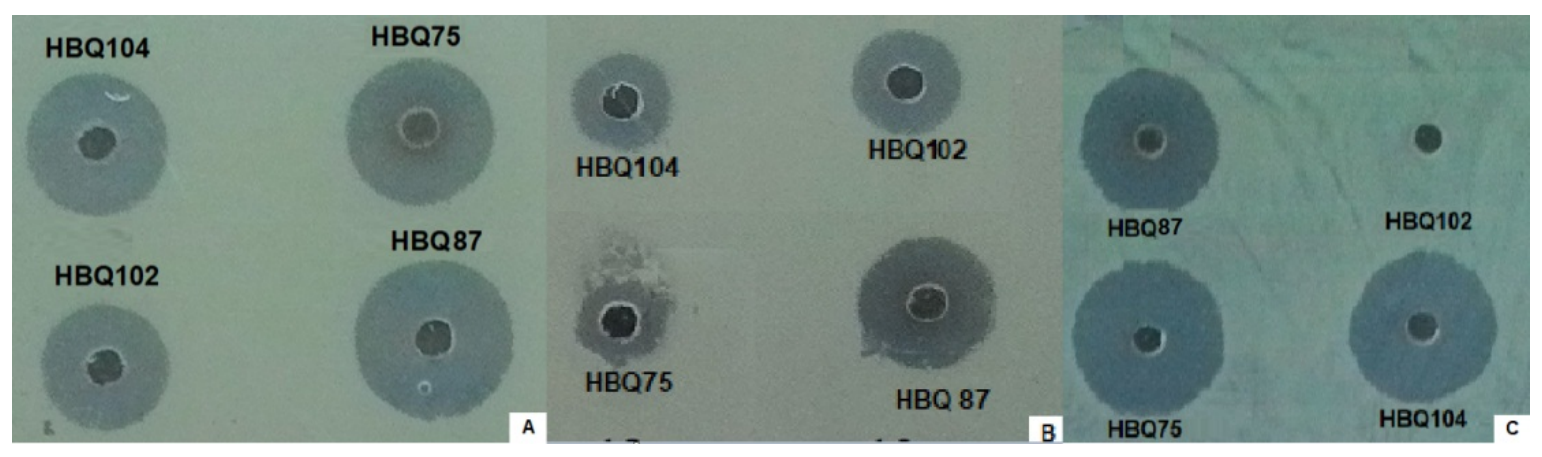

Figure 2. Antibacterial activities of cell-free supernatants of endophytic Streptomyces strains against Bacillus cereus (A), Escherichia coli (B) and Sarcina lutea (C).

Table 1. Antibacterial activities of cell-free culture supernatants of the four Streptomyces spieces againsts microbes.

\begin{tabular}{|c|c|c|c|c|c|c|c|c|c|c|}
\hline \multirow{3}{*}{$\begin{array}{l}\text { Species (GenBank } \\
\text { Accession No.) }\end{array}$} & \multirow{3}{*}{ Organ } & \multicolumn{9}{|c|}{ Inhibition zone (D-d,mm) } \\
\hline & & \multicolumn{9}{|c|}{ Microbes tested } \\
\hline & & 1 & 2 & 3 & 4 & 5 & 6 & 7 & 8 & 9 \\
\hline $\begin{array}{l}\text { S. fulvissimus HBQ75 } \\
\text { (MF796970) }\end{array}$ & Root & $12.9^{e} \pm 0.02$ & $15.5^{c} \pm 0.31$ & $0^{f}$ & $21.2^{\mathrm{a}} \pm 0.24$ & $0^{f}$ & $21.0^{\mathrm{a}} \pm 0.11$ & $14.1^{\mathrm{d}} \pm 0.38$ & $18.6^{b} \pm 0.56$ & $0^{f}$ \\
\hline $\begin{array}{l}\text { S. parvulus HBQ87 } \\
\text { (KR076807) }\end{array}$ & Root & $24.2^{\mathrm{a}} \pm 0.09$ & $20.3^{\mathrm{c}} \pm 0.4$ & $0^{\mathrm{e}}$ & $21.8^{\mathrm{b}} \pm 0.76$ & $0^{\mathrm{e}}$ & $18.0^{\mathrm{d}} \pm 0.36$ & $25.2^{\mathrm{a}} \pm 0.08$ & $17.9^{\mathrm{d}} \pm 0.42$ & $0^{\mathrm{e}}$ \\
\hline $\begin{array}{l}\text { S. pratensis HBQ102 } \\
\text { (MF796968) }\end{array}$ & Stem & $17.4^{\mathrm{c}} \pm 0.05$ & $19.6^{a} \pm 0.05$ & $0^{\mathrm{e}}$ & $19.0^{\mathrm{a}} \pm 0.36$ & $0^{\mathrm{e}}$ & $0^{\mathrm{e}}$ & $18.5^{\mathrm{b}} \pm 0.22$ & $15.6^{\mathrm{d}} \pm 0.52$ & $0^{\mathrm{e}}$ \\
\hline $\begin{array}{l}\text { S. ribosidificus HBQ104 } \\
\text { (MF796972) }\end{array}$ & Leaf & $13.3^{\mathrm{e}} \pm 0.1$ & $16.8^{\mathrm{c}} \pm 0.28$ & $0^{f}$ & $16.1^{\mathrm{c}} \pm 0.27$ & $0^{f}$ & $14.3^{\mathrm{d}} \pm 0.46$ & $20.6^{\mathrm{a}} \pm 0.13$ & $17.1^{\mathrm{b}} \pm 0.62$ & $0^{f}$ \\
\hline
\end{tabular}

Microbes tested: 1. Escherichia coli ATCC 11105; 2. Proteus vulgaris ATCC 49132; 3. Salmonella Typhimurium ATCC 14028; 4. Pseudomonas aeruginosa ATCC 9027; 5. Enterobacter aerogenes ATCC 13048; 6. Sarcina lutea ATCC 9341; 7. Methicillinresistant Staphylococcus epidermidis ATCC 35984; 8. Bacillus cereus ATCC 11778; 9. Candida albicans ATCC 10231. Values with different letters are significantly different according to Fisher LCD test $(P<0.05)$.

Specifically, all the four Streptomyces strains were able to inhibit the growth of three Gram-positive bacteria (B. cereus, P. vulgaris and MRSE) and two
Gram-negative bacteria (E. coli and P. aeruginosa), but all of them showed negative activity against the growth of E. aerogenes, Salmonella Typhimurium and $C$. 
albicans (Table 1). Three strains $S$. fulvissimus HBQ75, S. parvulus HBQ87 and S. ribosidificus HBQ104 exhibited the inhibitory activity against six microbes, while $S$. pratensis HBQ102 was active against five microbes (Table 1). S. fulvissimus HBQ75 exhibited highest antimicrobial activities towards two microbial species including $B$. cereus and $S$. lutea, while $S$. parvulus HBQ87 showed the highest inhibitory activity against four pathogens $E$. coli, $P$. aeruginosa, $P$. vulgaris and MRSE. It is worth noting that $S$. fulvissimus $\mathrm{HBQ75}$ and $S$. parvulus HBQ87 were isolated from the roots of $C$. cassia and they exhibited higher antimicrobial activities than $S$. pratensis HBQ102 and S. ribosidificus HBQ104 which were isolated from the stems and leaves of the host plant, respectively. Infact, the root of medicinal plants is the most suitable environment for the growth of endophytic microorganisms since this organ directly contacts to soils and its functions are to absorb water and nutrients from the soil (Golinska et al., 2015).

In fact, many new and broad-spectrum antibiotics have been isolated from endophytic actinomycetes associated with medical plants particularly from Streptomyces (Qin et al., 2009; Christina et al., 2013; Golinska et al., 2015). For instance, newly described antibiotics munumbicines isolated from endophytic Streptomyces NRRL 30562 associated with Australian medicinal plant Kennedia nigriscans were active against pathogenic fungi, Plasmodium species and various pathogenic bacteria including Bacillus anthracis, Streptococcus pneumoniae, Enterococcus faecalis (Christina et al., 2013). Interestingly, these new antibiotics also had strong active against multidrug-resistant pathogens such as methicillinresistant Staphylococcus aureus, vancomycinresistant strain of Enterococcus faecalis and multidrug-resistant Mycobacterium tuberculosis (Castillo et al., 2002). In agreement with previous studies, the results of our study underlined that endophytic actinomycete Streptomyces associated with medicinal plants could be potential candidates of valuable bioactive compounds.

\section{Detection of secondary metabolite biosynthesis genes}

It has been well-demonstrated that PKS and NRPS enzymes are involved in biosynthesis of valuable secondary metabolites in microorganisms such as antibitoics, antioxidase, antitumors, antimicrobials etc. (Minotti et al., 2004). Therefore, in order to predict the potential for biosynthesis of important bioactive compounds, the presence of genes $p k s-\mathrm{I}, p k s-\mathrm{II}$ encoding for PKS-I and PKS-II, respectively, and nrps encoding for NRPS in the four Streptomyces strains was investigated. Analysis of PCR results (Figure 3) showed that all the four Streptomyces strains possessed at least one of the biosynthetic genes (Table 2).
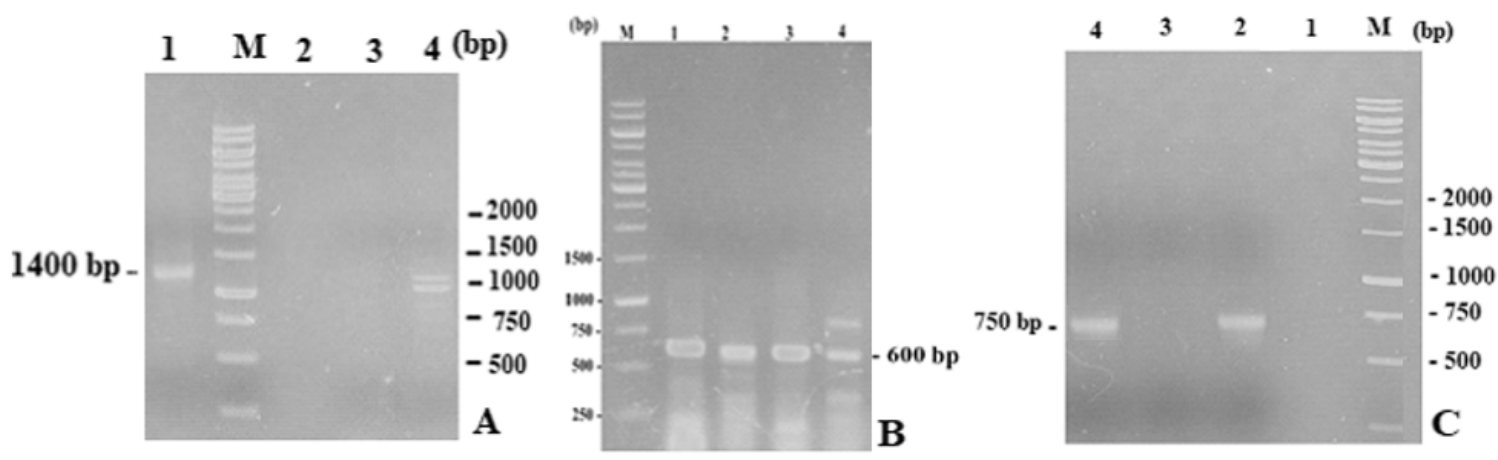

Figure 3. Agarose gel electrophoresis of the biosynthetic gene amplification products. (A) $1400 \mathrm{bp}$ fragments of pks-I genes, (B) $600 \mathrm{bp}$ fragments of pks-II genes, and (C) $750 \mathrm{bp}$ fragments of nrps genes. Lane M: $1 \mathrm{~kb}$ molecular weight marker; lane 1: HBQ104; lane 2: HBQ75; lane 3: HBQ102; lane 4: HBQ87.

In brief, S. parvulus HBQ87 and S. ribosidificus HBQ104 were positive for the $p k s$-I with approximate amplicon size of $1400 \mathrm{bp}$, all the four strains were positive for the pks-II (approximate amplicon size of $600 \mathrm{bp}$ ), while $S$. fulvissimus
HBQ75 and $S$. parvulus HBQ87 possessed the nrps gene (approximate amplicon size of $750 \mathrm{bp}$ ) (Table 2). Thus, S. parvulus HBQ87 possessed all three biosynthetic genes, whereas $S$. pratensis HBQ102 carried only the $p k s$-II gene and the remaining strains 
possessed the combination of two genes $p k s-I$ and $p k s$-II or pks-II and nrps. Since these endophytic Streptomyces strains have different parterns of biosynthetic genes, this genotypic data suggests that a broad array of bioactive compounds could be obtained from them. In agreement with previous studies (Qin et al., 2009; Passari et al., 2015), the pks and nrps genes are commonly found in the Streptomyces. Nevertheless, Streptomyces species isolated from different sources showed the different capacity of antibiotic production. The antimicrobial activities combined with the genotypic data suggest that the four endophytic Streptomyces species isolated from $C$. cassia would be potential candidates of novel bioactive compounds.

Table 2. The amplification results of genes encoding for PKSI, PKS-II, NRPS enzymes from the four Streptomyces strains.

\begin{tabular}{lccc}
\hline & \multicolumn{3}{c}{ Biosynthetic gene } \\
\hline \multicolumn{1}{c}{ Species } & pks-I & pks-II & nrps \\
\hline S. fulvissimus HBQ75 & - & + & + \\
\hline S. parvulus HBQ87 & + & + & + \\
\hline S. pratensis HBQ102 & - & + & - \\
\hline S. ribosidificus & + & + & - \\
HBQ104 & & & \\
\hline
\end{tabular}

Note: +: possitive result; -: negative result

\section{Production capacity of anthracyclines-like antibiotics}

Anthracyclines-like antibiotics are important antitumor agents and are widely used for cancer treatments in clinics (Nakashima et al., 2013). Recently, new anthracyclines have been isolated from endophytic actinomyces, particularly in Streptomyces species such as Streptomyces sp. YIM66403, Streptomyces scabrisporus (Christina et al., 2013; McGowan et al., 2017). Using the pigment identification method, our study revealed all the four strains $S$. parvulus HBQ87, S. pratensis HBQ102 and $S$. ribosidificus HBQ104 positive for the production of anthracyclines-like antibiotics. In fact, anthracyclines are produced via the biosynthetic polyketide pathway and are mainly found in the Streptomyces (Metsä et al., 2007). This result is concordant with the genotypic data since all these Streptomyces strains carried at least one pks gene. So far, the biosynthesis of doxorubicin and daunorubicin (belonged to anthracyclines) was demonstrated in $S$. parvulus species (Otten et al., 1995; Han et al., 2011). The finding in our study suggests that $S$. parvulus HBQ87 could able to produce the similar antitumor agents and the other Streptomyces species would be potential candidates of new antitumors (Trease, Evans, 1996; Zhang et al., 2014; Ventola, 2015).

\section{Cytotoxic properties of the cell-free supernatants} of culture broth of endophytic Streptomyces strains

In order to evaluate the production capacity of antitumor agents, the cell-free supernatants (CFSs) of the four Streptomyces strains was used for the cytotoxic assay against three human carcinoma cell lines including A549, Hep3B and MCF7 cells (Table 3).

Among the four Streptomyces strains, the CFSs of three strains including $S$. fulvissimus HBQ75, S. parvulus $\mathrm{HBQ} 87$ and $S$. pratensis HBQ102 were positive for at least one type of carcinoma cell lines tested at concentration of $100 \mu \mathrm{g} / \mathrm{mL}$, while $S$. ribosidificus HBQ104 was negative at the both concentrations tested. The CFSs of the three strains were positive to MCF7 cells in which the CFSs of $S$. fulvissimus HBQ75 showed highest activity (survival variability between $25 \%$ and $28 \%$ at the concentrations of $100 \mu \mathrm{g} / \mathrm{mL}$ and $30 \mu \mathrm{g} / \mathrm{mL}$, respectively). Interestingly, at a low concentration of $30 \mu \mathrm{g} / \mathrm{ml}$, S. fulvissimus HBQ75 and S. parvulus HBQ87 were active against Hep3B, while $S$. fulvissimus $\mathrm{HBQ75}, S$. parvulus $\mathrm{HBQ} 87$ and $S$. pratensis HBQ102 were active against MCF7. The EACE of HBQ87 was positive for the three cell lines, also this was the only strain positive to A549 cells. S. parvulus HBQ87 also exhibited strong inhibitory effect against Hep3B cells (Table 3). Thus, the results obtained in this study were considerable to results in previous studies (Khieu et al., 2015; Passari et al., 2015). All together, the detection of three biosynthetic genes, the activity of anthracyclines-like antibiotics and cytotoxic effects towards the three different human carcinoma cell lines suggests that the $S$. parvulus HBQ87 could be the most potential candidate among the four selected endophytic Streptomyces species for production of valuable bioactive compounds. 
Table 3. Cytotoxic effects against human carcinoma cells Hep3B, MCF7 and A549 of ethyl acetate extract of the four Streptomoyces species.

\begin{tabular}{|c|c|c|c|c|}
\hline \multirow{2}{*}{ Species } & \multirow{2}{*}{$\begin{array}{l}\text { Concentration } \\
(\mu \mathrm{g} / \mathrm{mL})\end{array}$} & \multicolumn{3}{|c|}{ Survival variability (SV \% \pm SD) } \\
\hline & & A549 & Нер3В & MCF7 \\
\hline \multirow{2}{*}{ S. fulvissimus HBQ75 } & 30 & $73.48^{\mathrm{C}} \pm 1.22$ & $47.84^{d} \pm 2.18$ & $28.71^{g} \pm 0.74$ \\
\hline & 100 & $50.84^{g} \pm 1.48$ & $39.55^{\mathrm{e}} \pm 2.42$ & $25.62^{h} \pm 1.02$ \\
\hline \multirow{2}{*}{ S. parvulus HBQ87 } & 30 & $54.22^{f} \pm 2.52$ & $32.70^{f} \pm 0.76$ & $31.12^{f} \pm 0.80$ \\
\hline & 100 & $37.69^{i} \pm 1.04$ & $31.65^{f} \pm 1.25$ & $25.12^{h} \pm 1.28$ \\
\hline \multirow{2}{*}{ S. pratensis HBQ102 } & 30 & $74.65^{b . c} \pm 0.45$ & $52.03^{\mathrm{C}} \pm 1.64$ & $34.26^{\mathrm{e}} \pm 1.55$ \\
\hline & 100 & $61.81^{d} \pm 0.73$ & $47.96^{d} \pm 1.98$ & $25.58^{h} \pm 1.28$ \\
\hline \multirow{2}{*}{ S. ribosidificus HBQ104 } & 30 & $81.51^{\mathrm{a}} \pm 1.87$ & $66.57^{\mathrm{a}} \pm 1.46$ & $81.77^{\mathrm{a}} \pm 0.78$ \\
\hline & 100 & $56.66^{\mathrm{e}} \pm 2.85$ & $57.58^{\mathrm{b}} \pm 1.52$ & $77.51^{b} \pm 0.25$ \\
\hline \multirow{2}{*}{ Camptothecin } & $0.1 \mu \mathrm{M}$ & $76.00^{\mathrm{b}} \pm 2.27$ & $52.03^{c} \pm 3.03$ & $65.63^{c} \pm 2.20$ \\
\hline & $10 \mu \mathrm{M}$ & $41.77^{h} \pm 1.25$ & $28.27^{9} \pm 2.64$ & $41.92^{d} \pm 2.85$ \\
\hline
\end{tabular}

SV \pm SD: Survival variability \pm Standard deviation. Values $\leq 50 \%$ was considered as positive activity (highlighted in the table). Values with different letters are significantly different according to Fisher LCD test $(P<0.05)$.

\section{CONCLUSION}

The endophytic actinomycete strains $S$. fulvissimus HBQ75, S. parvulus HBQ87, S. pratensis HBQ102 and $S$. ribosidificus HBQ104 exhibited broad-spectrum antibacterial activities against at least five different pathogens, had considerable cytotoxic activities towards different human carcinoma cell lines and possessed genes involved in biosynthetic pathways of secondary bioactive metabolites. Among them, S. parvulus HBQ87 was proved to be the potential producer of valuable secondary metabolites. Further study needs to isolate and elucidate structures of bioactive compounds derived from $S$. parvulus HBQ87.

Acknowledgements: This work is funded by Graduate University of Science and Technology, VAST under the grant number GUST.STS.ĐT2017SH03. We are grateful with the support of National Key Laboratory of Gene Technology, Institute of Biotechnology (IBT) and University of Science and Technology of Hanoi (USTH), VAST for implementing this project.

\section{REFERENCE}

Ayuso SA, Genilloud O (2005) New PCR primers for the screening of NRPS and PKS-I systems in actinomycetes: detection and distribution of these biosynthetic gene sequences in major taxonomic groups. Microbiol Ecol 49(1): 10-24.
Bérdy J (2012) Thoughts and facts about antibiotics: where we are now and where we are heading. J Antibiot 65(8): 385-391.

Castillo UF, Strobel GA, Ford EJ, Hess WM, Porter H, Jensen JB, Albert H, Robison R, Condron MA,Teplow DB (2002) Munumbicins, wide-spectrum antibiotics produced by Streptomyces NRRL 30562, endophytic on Kennedia nigriscansa. Microbiology 148(9): 2675-2685.

Christina A, Christapher V, Bhore SJ (2013) Endophytic bacteria as a source of novel antibiotics: an overview. Pharmacol Rev 7(13): 11.

Golinska P, Wypij M, Agarkar G, Rathod D, Dahm H, Rai M (2015) Endophytic actinobacteria of medicinal plants: diversity and bioactivity. A Van Leeuw 108(2): 267-289.

Han AR, Park JW, Lee MK, Ban YH, Yoo YJ, Kim EJ, Kim E, Kim B-G, Sohng JK, Yoon YJ (2011) Development of a Streptomyces venezuelae-based combinatorial biosynthetic system for the production of glycosylated derivatives of doxorubicin and its biosynthetic intermediates. Appl Environ Microbiol 77(14): 4912-4923.

Khieu TN, Liu MJ, Nimaichand S, Quach NT, Chu Ky S, Phi QT, Vu TT, Nguyen TD, Xiong Z, Prabhu DM (2015) Characterization and evaluation of antimicrobial and cytotoxic effects of Streptomyces sp. HUST012 isolated from medicinal plant Dracaena cochinchinensis Lour. Front Microbiol 6: 574.

Kumar S, Stecher G, Tamura K (2016) MEGA7: molecular evolutionary genetics analysis version 7.0 for bigger datasets. Mol Biol Evol 33(7): 1870-1874.

Pham NL, Dang TTD, Vu THN, Chu KS, Vu TT, Phi QT 
(2017) Distribution and antimicrobial activity of endophytic actinomycetes isolated from Litsea cubeba (Lour.) Pers. in northern provinces of Vietnam. Vietnam Journal of Science and Technology 55(5A): 160-168.

Matsumoto A, Takahashi Y (2017) Endophytic actinomycetes: promising source of novel bioactive compounds. J Antibiot 70(5): 514-519.

McGowan JV, Chung R, Maulik A, Piotrowska I, Walker JM, Yellon DM (2017) Anthracycline chemotherapy and cardiotoxicity. Cardiovasc drugs and ther 31(1): 63-75.

Metsä KM, Niemi J, Mäntsälä P, Schneider G (2007) Anthracycline biosynthesis: genes, enzymes and mechanisms. Top Curr Chem 282: 101-140.

Metsä KM, Salo V, Halo L, Hautala A, Hakala J, Mäntsälä P, Ylihonko K (1999) An efficient approach for screening minimal PKS genes from Streptomyces. FEMS Microbiol Lett 180(1): 1-6.

Minotti G, Menna P, Salvatorelli E, Cairo G, Gianni L (2004) Anthracyclines: molecular advances and pharmacologic developments in antitumor activity and cardiotoxicity. Pharmcol Rev 56(2): 185-229.

Nakashima T, Okuyama R, Kamiya Y, Matsumoto A, Iwatsuki M, Inahashi Y, Yamaji K, Takahashi Y, Ōmura S (2013) Trehangelins A, B and C, novel photo-oxidative hemolysis inhibitors produced by an endophytic actinomycete, Polymorphospora rubra K07-0510. J Antibiot 66(6): 311-317.

Otten SL, Ferguson J, Hutchinson CR (1995) Regulation of daunorubicin production in Streptomyces peucetius by the dnrR2 locus. J Bacteriol 177(5): 1216-1224.

Passari AK, Mishra VK, Saikia R, Gupta VK, Singh BP (2015) Isolation, abundance and phylogenetic affiliation of endophytic actinomycetes associated with medicinal plants and screening for their in vitro antimicrobial biosynthetic potential. Front Microbiol 6: 273.
Phan H, Mai L, Nguyen Vu, Hong L, Nguyen Thi, Van Hieu $\mathrm{N}$ (2016) Biological characteristics and antimicrobial activity of endophytic Streptomyces sp. TQR12-4 isolated from elite Citrus nobilis cultivar Ham Yen of Vietnam. $J$ Microbiol 2016: 1-7.

Qin S, Li J, Chen HH, Zhao GZ, Zhu WY, Jiang CL, Xu LH, Li WJ (2009) Isolation, diversity, and antimicrobial activity of rare actinobacteria from medicinal plants of tropical rain forests in Xishuangbanna, China. Appl Environ Microbiol 75(19): 6176-6186.

Salam N, Khieu TN, Liu MJ, Vu TT, Chu KS, Quach NT, Phi QT, Narsing Rao MP, Fontana A, Sarter S (2017) Endophytic Actinobacteria Associated with Dracaena cochinchinensis Lour.: Isolation, Diversity, and Their Cytotoxic Activities. BioMed Res Int 2017: 1-11.

Trease G, Evans W (1996) Textbook of Pharmacognosy, London. Bailliare Tindall 12(193): 336.

Ventola CL (2015) The antibiotic resistance crisis: part 1: causes and threats. Pharm Therapeut 40(4): 277.

Vu HNT, Nguyen DT, Nguyen HQ, Chu HH, Chu SK, Van Chau M, Phi QT (2018) Antimicrobial and cytotoxic properties of bioactive metabolites produced by Streptomyces cavourensis YBQ59 isolated from Cinnamomum cassia Prels in Yen Bai Province of Vietnam. Curr Microbiol 75(10): 1247-1255.

Vu THN, Nguyen QH, Dinh TML, Quach NT, Khieu TN, Hoang H, Son CK, Vu TT, Chu HH, Lee J (2019) Endophytic actinomycetes associated with Cinnamomum cassia Presl in Hoa Binh province, Vietnam: Distribution, antimicrobial activity and, genetic features. J Gen Appl Microbiol 2019: 1-18.

Zhang J, Wang JD, Liu CX, Yuan JH, Wang XJ, Xiang WS (2014) A new prenylated indole derivative from endophytic actinobacteria Streptomyces sp. neau-D50. Nat Prod Res 28(7): 431-437.

\title{
HOẠT TÍNH KHÁNG KHUẨN VÀ GÂY ĐộC TẾ BÀO CỦA XẠ KHUẨN NỘI SINH STREPTOMYCES PHÂN LẬP TỬ CÂY QUẾ (CINNAMOMUM CASSIA PRESL) Ở VIỆT NAM
}

\author{
Nguyễn Quang Huy 1,2,*, Vũ Thị Hạnh Nguyên ${ }^{2, *}$, Nguyễn Văn Thế2 ${ }^{2}$ Bùi Thị Liên², Lê Thị Thu Hằng ${ }^{3}$, \\ Phí Quyết Tiến ${ }^{2,1 \bowtie}$ \\ ${ }^{1} H o c$ viện Khoa hoc và Công nghệ (GUST), Viện Hàn lâm Khoa học và Công nghệ Việt Nam (VAST) \\ ${ }^{2}$ Viện Công nghệ sinh hoc (IBT), Viện Hàn lâm Khoa học và Công nghệ Việt Nam (VAST) \\ ${ }^{3}$ Truờng Đại học Khoa học và Công nghệ Hà Nội (USTH), Viện Hàn lâm Khoa học và Công nghệ Việt Nam \\ (VAST)
}

\section{TÓM TẮT}

Việt Nam được xếp vào nhóm quốc gia có độ đa dạng cây dược liệu cao trên thế giới, tuy nhiên rất ít nghiên cứu về sự phân bố, mức độ đa dạng và hoạt tính sinh học của xạ khuẩn nội sinh trên cây dược liệu. Mục tiêu của 
nghiên cứu này là nhằm đánh giá hoạt tính kháng khuẩn và gây độc tế bào của các chủng xạ khuẩn nội sinh thuộc nhóm Streptomyces gồm Streptomyces sp. HBQ75, HBQ87, HBQ102 và HBQ104 được phân lập từ những bộ phận khác nhau (rễ, thân hoặc lá) của cây quế Cinnamomum cassia Presl. Phân tích trình tự gene 16S rRNA và cây phả hệ cho thấy chúng thuộc bốn loài xạ khuẩn khác nhau là Streptomyces fulvissimus HBQ75, Streptomyces parvulus HBQ87, Streptomyces pratensis HBQ102 và Streptomyces ribosidificus HBQ104. Các chủng này có hoạt tính kháng khuẩn phổ rộng ức chế sự phát triển của ít nhất $5 / 9$ chủng vi sinh vật được thử nghiệm, trong đó S. parvulus HBQ87 thể hiện hoạt tính tốt nhất (đường kính vòng ức chế $>20 \mathrm{~mm}$ ). S. parvulus HBQ87 mang cả ba gen $p k s-\mathrm{I}, p k s-\mathrm{II}$ và $n r p s$, trong khi ba chủng còn lại chỉ mang từ một đến hai gen. Bốn chủng Streptomyces đều có khả năng sinh kháng sinh thuộc nhóm anthracyclines. Dịch chiết lên men $S$. parvulus HBQ87 ức chế sinh trưởng các dòng tế bào ung thư gồm $\mathrm{Hep} 3 \mathrm{~B}, \mathrm{MCF} 7$ và $\mathrm{A} 549$ ở cả hai nồng độ thử nghiệm $(30 \mu \mathrm{g} / \mathrm{mL}$ và 100 $\mu \mathrm{g} / \mathrm{mL}$ ), trong khi $S$. fulvissimus HBQ75 và $S$. pratensis HBQ102 ức chế các tế bào Hep3B và MCF7. Như vậy, các đặc điểm kiểu hình và kiểu gen của bốn chủng Streptomyces cho thấy, chúng có khả năng sinh tổng hợp các hoạt chất sinh học phổ rộng khác nhau. S. parvulus HBQ87 là chủng có tiềm năng nhất để sinh hợp chất kháng khuẩn và kháng tế bào ung thư.

Từ khóa: Anthracyclines, cây quế, hoạt tính kháng khuẩn, kháng tế bào ung thu, xạ khuẩn nội sinh 